\title{
DESCRIPTION OF UNIO PAHANGENSIS, N.SP., FROM THE RIVER PAHANG.
}

\author{
By Edgar A. Sinth, F.Z.S., etc. \\ Read 9th June, 1899.
}

\section{Unio Pahangensis.}

Testa elongata, valde inæquilateralis, mediocriter compressa, antice rotundata, postice angustata, subcuneiformis, periostraco fusco induta, lineis incrementi validis striata; valvæ mediocriter crassæ, ad apicem erosæ, intus in medio dilutissime flavo-salmoneæ, infra et antice ad marginem cæruleo-albæ, postice purpurascentes; margo dorsi anticus

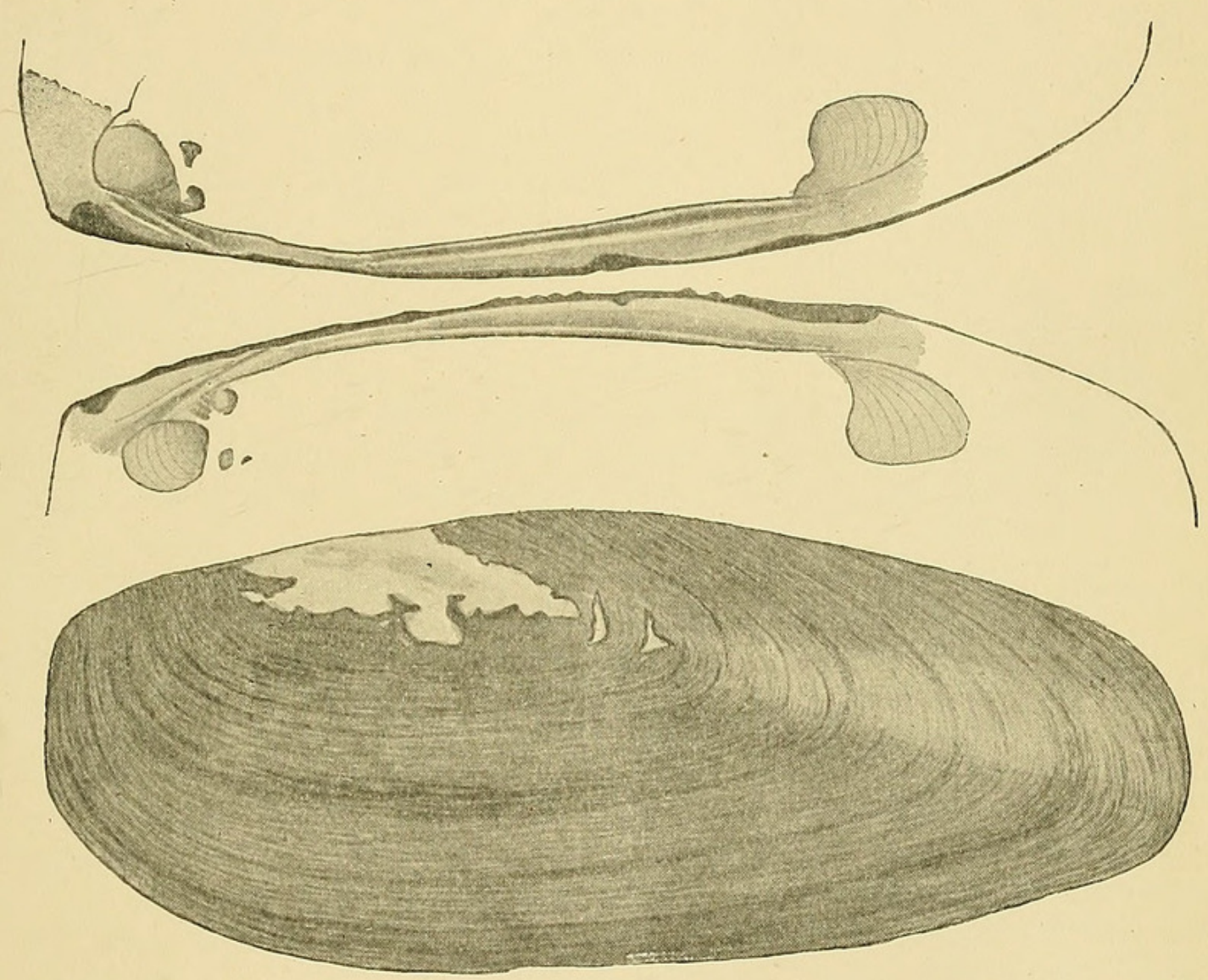

Unio Pahangensis, n.sp.

subdescendens, posticus fere rectus, subhorizontalis, ventralis parum curvatus, antice sursum arcuatus; cicatrix anterior breviter piriformis, bene impressa, postica major, superficialis ; linea pallii antice crenulata; cicatrices pedis muscularum tres inæquales; dentes anteriores duo, quorum superior gracilis, elongatus, interior crassior, rugosus, substriatus, posticus unicus elongatus, rectus; dens unicus 
anterior valvæ sinistræ elongatus, rugosus, dentes duo posteriores recti, æquales. Long. 131, alt. 50, diam. $24 \mathrm{~mm}$.

Hab.-Pahang River, Malay Peninsula.

This species is remarkable for its elongate form. The colour of the periostracum is dark olive-brown, with here and there a darker concentric zone. There is also an indication of two or three obscure rays on the posterior area between the rounded umbonal ridge and the dorsal margin. The lines of growth are rather strong, and are faintly sinuated at their anterior termination.

The specimen described has been presented to the British Museum (Natural History) by Mr. L. Lindsay, who possesses a second specimen. They were picked up on the banks of the Pahang about ten years ago by a relative of Mr. Lindsay's. 


\section{$2 \mathrm{BHL}$ Biodiversity Heritage Library}

1899. "DESCRIPTION OF UNIO PAHANGENSIS, N.SP., FROM THE RIVER

PAHANG." Proceedings of the Malacological Society of London 3, 315-316.

View This Item Online: https://www.biodiversitylibrary.org/item/100098

Permalink: https://www.biodiversitylibrary.org/partpdf/202714

\section{Holding Institution}

Field Museum of Natural History Library

\section{Sponsored by}

Smithsonian

\section{Copyright \& Reuse}

Copyright Status: Public domain. The BHL considers that this work is no longer under copyright protection.

This document was created from content at the Biodiversity Heritage Library, the world's largest open access digital library for biodiversity literature and archives. Visit BHL at https://www.biodiversitylibrary.org. 